\title{
The quest for the understanding of Religious Studies: Seeing dragons
}

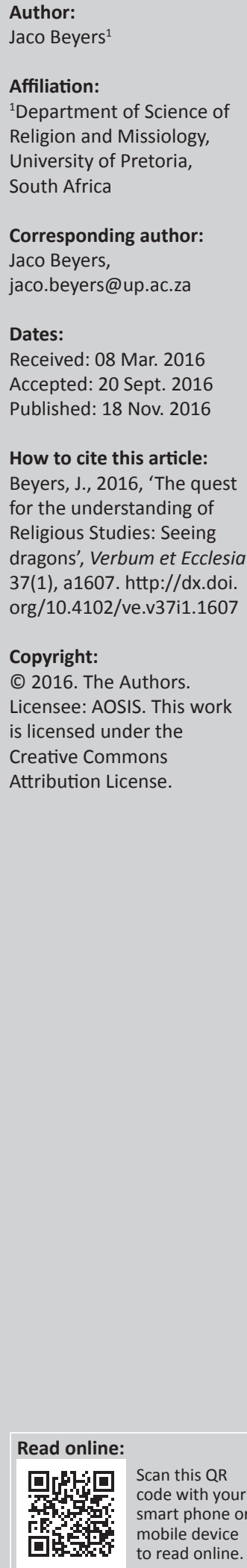

Religious Studies is concerned with studying religion or the absence thereof. The concept of religion has been discussed, disliked and dissected over centuries. Some have predicted the disappearance of religion, others have predicted the changing of location from the public to the private sphere and some even the re-emergence of religion. In trying to determine the place and relations of Religious Studies an understanding of what religion entails is necessary. It is clear that Religious Studies consists of a multiform subject field and a variety of disciplines with a multiplicity of issues, interests and topics together with a wide variety of approaches and methods. Some scholars have described religion as a 'saturated phenomenon' trying to indicate how the diversity of elements described as religious came to shroud the true subject matter. All these hindrances on the road to comprehending religion are like dragons preventing one from completing a (holy!) quest. This article does not want to provide new answers to an old debate. In this sense this article is not an attempt at slaying the dragons but identifying them. Three issues (dragons) are discussed. How religion, the object of Religious Studies, should be viewed? What methods are employed by Religious Studies and the relatedness of Religious Studies to Theology? In the end the article wants to provide direction on how Religious Studies, as academic discipline, can collaborate with research in Theology.

Intradisciplinary and/or interdisciplinary implications: This article discusses the development of the subject of Religious Studies by providing a historic overview of sociological influences on the development. In this sense this article is not an attempt at slaying the dragons but identifying them. Three issues (dragons) are discussed: how religion, the object of Religious Studies, should be viewed; what methods are employed by Religious Studies and the relatedness of Religious Studies to Theology (with implications for interdisciplinary collaboration). In the end the article wants to provide direction in how Religious Studies as academic discipline can collaborate with research in Theology.

\section{Introduction}

\section{What is in a name?}

Entering the metaphorical forest of knowledge on religious matters is indeed a precarious endeavour. It becomes a place where one can easily loose one's way and end up engaging with objects considered to be the true objects to investigate just to realise an illusion has captured one's attention. Danger lurks on the quest to determine what Religious Studies is.

This article wants to identify several 'dragons' that might be encountered on this quest to make sense of Religious Studies. The first dragon is the question as to what religion is and what constitutes its nature. A second dragon pertains to the relevant methodology applied within Religious Studies. A third dragon encountered will be the question as to the relation between Religious Studies and Theology. On this journey through dragon country the intention is to pave a way towards a responsible location for Religious Studies within a Faculty of Theology.

The field of study focused on in the study of religion is known by different names. Krüger (1982:9) indicates how this field has been called science of religion, comparative (study of) religion, history of religions, religious studies and religiology, all equivalents to the German Religionswissenschaft. ${ }^{1}$ The reason for the uncertainty about the name Krüger (1982:9) says is a reflection of the uncertainty about the inner structure and coherence. The fact of the matter is that the different names reflect different contexts. During some phases of scientific development certain religious matters enjoyed more attention than other matters. This is reflected in the different names. 
The earliest phase was the literary phase (also known as the philological phase): sacred books and texts (e.g. Sanskrit texts, books of Confucianism and Taoism) were translated. Max Müller, an English scholar of German descent, contributed hugely to this ambitious effort.

A following phase was that of History of Religion (German: Religionsgeschichte), a period during which the historical approach dominated. It was soon complemented by anthropology (then known as ethnology - Afrikaans: Volkekunde or Antropologie). Anthropology may in a certain sense be termed the twin of History of Religion, as it was initiated in the same period as Science of Religion. Edward B. Tylor and James J. Frazer were prominent historians of religion and excelled in comparative religion. Frazer was also interested in anthropology and integrating anthropological perspectives in History of Religion.

The name Comparative Religion was used during the latter part of the 19th century and the earlier part of the 20th century in the English-speaking world. At that time it reflected an evolutionistic approach. It aimed to study the various religions and religious phenomena with a view of constructing a system of comparison and organisation in terms of lower and higher levels of religious development through evolution. Currently it is also used for what is known as Phenomenology of Religion, a subdiscipline of and approach in Science of Religion. Results from historical studies gradually grew into a flood of information. The need for standardisation and classification became evident. Many historians of religion started to experiment with comparison and classification of material. This was the beginning of the comparative approach within History of Religion, which eventually developed into Phenomenology of Religion.

The existence of Religious Studies as academic discipline is the product of Enlightenment thought (Olson 2011:13). Religious Studies according to Olson (2011:13) started out with the distinction between Science of Religion (Religionswissenschaft) in contrast to natural sciences (Naturwissenschaft). In fact Religionswissenschaft formed a subdiscipline of what was known in the German-speaking world as Geisteswissenschaft (sciences of human spirit), or better known as humanities. The English use of the word 'science' tends to refer only to natural sciences and does not include humanistic or social sciences as does the German term Wissenschaft. Religious Studies is regarded as science but belonging to the humanities or social sciences. At the first conference for the History of Religion held in Paris in 1900 it was mentioned that Religionswissenschaft was still a young discipline with its origin as academic discipline during the late 19th century (Pannenberg 1973:361).

The Enlightenment also saw the rise of new subjects such as sociology and psychology. Scholars from these fields were interested in religion and applied the insights and principles of their subjects to this field. This led to new subdisciplines in Science of Religion. The French scholar Auguste Comte may be considered the father of Sociology of Religion. Emile Durkheim and Bronislaw Malinowski succeeded him.

Psychology of Religion may be traced back to Ludwig Feuerbach, although he was not a psychologist. The founding father of modern psychology was the Austrian physician, Sigmund Freud. He was also interested in Psychology of Religion. Another prominent figure was the American, William James. However, it was the contribution of the Swiss psychiatrist Carl Jung who died in the middle of the 20th century that impacted greatly on this subject and on Phenomenology of Religion.

One of the traits of scholarship in the 19th century was a tendency to form schools of thought. Many of the abovementioned approaches formed the bases of schools that competed for dominance in the field of religion. Science of Religion had not been consolidated as a fully recognised discipline yet. However, the situation changed gradually. At the end of the 19th century Science of Religion was accepted as a true academic discipline and many of these approaches were recognised as subdisciplines of Science of Religion.

The name Science of Religion (German: Religionswissenschaft, Afrikaans: Godsdienswetenskap) was introduced during the 20th century and has since won wide acceptance. It is still used in the English-speaking world, especially North America. However, because the English are not comfortable with using 'science' for what is considered a discipline of scholarship, this term has been widely substituted by 'Religious Studies'. Eventually the discipline Science of Religion existed parallel to Religious Studies. The term Religion Studies is a newcomer to the field and is reserved for referencing to the study of religion from the field of education. This distinction between Religious and Religion Studies is based on a semantic argument. 'Religious' in Religious Studies is an adverbial description of the nature of the study undertaken, focusing on the study. With Religion Studies religion is used as a noun indicating the object to be studied. Because Religious Studies has become a fixed technical term internationally, it will be difficult to convince that another name change is necessary.

\section{What is religion and its nature?}

In order to understand what the study of religion entails, it might be necessary to investigate the nature of the subject field. Religion started with the arrival of Homo sapiens. For the past 100 years the general held theory among sociologists and archaeologists is that Homo sapiens appeared on the scene approximately 200000 years ago. Urban (2003:101) is of the opinion that Homo sapiens appeared only around 40000 years ago and that since then religious activities and development have been apparent. It is then safe to assume that religion only started when the first humans appeared on the Earth. This implies that religion is indeed a human invention and an activity directed at something or someone considered greater than human existence. Ever since the arrival of Homo sapiens the forms of religious expression became varied and 
more complex. To such an extent that it grew more difficult to determine when something can indeed be categorised as being religious. This quick mire of uncertainty of what is religious and what is religion warrants a warning: there be dragons here!

A first crucial distinction is to be made between religion and faith. The object of Religious Studies is religion. Religion in this comparison would designate the broader category, the system within which faith functions. Religion is the broader structure providing a frame for elements of faith. Faith on the other hand is the personal conviction, the doctrinal beliefs associated with a particular religion. Faith denotes a personal relationship between the divine and adherent to that particular faith. Based on this understanding we can speak of Christian faith or Muslim faith or Hindu faith, etc. On phenomenological level there might be many similarities between religions. The uniqueness of each religion lies on the level of faith. Study of religion is unbiased, focusing on being descriptive and explanatory. Studies of faith would be biased and prescriptive. In this regard a differentiation should be made between Religious Studies and Theological Religious Studies. Religious Studies is not concerned with matters of faith, therefore non-doctrinal or non-confessional. Theology would be interested in doctrinal matters and would study religions from a Christian theological interest and perspective. Theology then investigates the theological meaning of the common phenomenological structure of religions as well as the encounter between Christianity and other religions. Theology would then be concerned with matters of faith and Religious Studies with anything related to religion (Capps 1995:333).

Religious Studies is the academic study of religion (Capps 1995:339; Olson 2011:13) or the absence thereof. ${ }^{2}$ Mulder (1985:35) refines this by indicating that Religious Studies studies religion as an expression of human culture. That however is only half said: 'The field of religious studies is a bewildering jungle' (Braun 2000:5) ... prone to dragons residing in it! As illustration of the wide variety of topics associated with Religious Studies, Morreall and Sonn (2012:323-326) provides an extensive list of topics that fall in the scope of Religious Studies in the American Academy of Religion: elements such as Arts, Literature and Religion; Comparative Studies in Religion; Philosophy of Religion; Women and Religion; Critical Theory and Discourses on Religion; Cultural History of the Study of Religion; Law, Religion and Culture; Mysticism; Psychology, Culture and Religion; Religion and Ecology; Religion and Popular Culture; Religion, Media and Culture; Ritual Studies; Scriptural Reasoning; Animals and Religion; Cognitive Science and Religion; Music and Religion; Religion and Cities; Religion and Sexuality; Sociology of Religion; Religion and Medicine, et cetera. From this it is indeed difficult to determine what is the true object of Religious Studies and by what method this object ought to be studied?

2.Studying secularisation is part of the process of understanding religion.
To state that Religious Studies is concerned with studying religion requires an understanding of what religion is, an endeavour identified earlier in this study. This is problematic as the definition of what religion is still remains outstanding (Braun 2000:4; Schilderman 2014:176). The problem with defining religion is according to Braun (2000:4) that there are too many meanings and the meanings are too indeterminate to be of value. The purpose of this article is however not to attempt a discussion on the problem of defining religion. This has been dealt with properly elsewhere (cf. Beyers 2010:2). Cox (2010:3-7) provides direction on this matter by suggesting studying the groups of definitions has more value than studying the definitions themselves.

What is clear is that the elements needed to be present to constitute the minimum base for what can be labelled as religion are humans and the transcendental (also referred to as the holy, gods, metaphysical or the sacred). Humans from within this worldly existence express their relation to the transcendental ${ }^{3}$ (i.e. that which exists beyond the confines of this worldly existence) in various ways of which doctrine (beliefs), actions (rituals) and ethics are the most notable but not restricted to.

An investigation into the origin of the word 'religion' can provide a clue as to the intended meaning of the word. The word religion comes from the Latin religio, which means 'a binding together', implying the close connection of individuals or communities sharing the same beliefs (Thorpe 1992:6). Eventually religio came to denote the unity between a community and nature with the spiritual forces residing in nature (Thorpe 1992:6). The root of the word religio might have a dual origin: re-ligare, 'to connect' as was used by Augustine (Urban 2003:88), and religere, 'to follow closely' as was used by Cicero (Urban 2003:88). Religion therefore, it is safe to say, wants to refer to the passive connection between humans and gods as well as the active participation by humans in worshipping the gods (Urban 2003:88). Sundermeier (1999:27) adds another possible root, namely relegere, 'to engage again', emphasising the connection between two parties. Some Eastern religions however do not fit this description as they follow teachings rather than gods, if 'parties' only refers to gods and people.

It can however never be the intention to limit the meaning of the word religion to the relationship between humans and gods, as indeed some definitions intend. In this regard compare the way in which E.B. Tylor limits the meaning of religion to the acknowledging and worshipping of supernatural spirits and beings (in Cox 2010:3).

Religious Studies would be the academic study of human behaviour in relation to the transcendental (cf. Braun 2000:11). Study that is exclusively focused on an understanding of the transcendental is relegated to the discipline of Theology. The phenomenologist, Gerhardus van der Leeuw, identified this

3.There is currently an intensive debate on how the philosophy of Religious Studies views the metaphysical. Compare in this regard the response of Kevin Schilbrack (2016) to those who comment on his publication on this matter. 
dual approach by indicating that science can only talk about human actions in relation to God, but has no comment on God's actions (Van der Leeuw 1970:3). Religion is explained as a natural phenomenon (Braun 2000:13), whereas Theology would be described as a science engaged with the supernatural. Religious activities are studied and explained as humanly created devices to make sense of reality. Mulder (1985:35) talks in this regard of Religious Studies as science of culture. This demarcation implies that Religious Studies falls within the discourse which is part of the humanities, studying human behaviour. The study of religion is then seen as a contributing element in the pursuit of a science of human social life (Braun 2000:5). Braun (2000:13) is further of the opinion that the origin of these social sciences (i.e. anthropology, psychology, sociology) lies within their attempt to explain religion. Studying religion in this humanistic perspective will entail a trail of thought that it is not due to any effort from the gods that humans revere or fear them. It much rather is a case of humans creating gods to be revered and feared by humans.

This would be the typical Religious Studies conclusion. Theology produces a different answer. Compare in this regard Rudolf Otto's answer as a theological explanation of the origin of what he refers to as 'the Holy'. The Holy exists independently and autonomously from human existence. Humans merely become aware of the existence of the indescribable Holy (Otto 1932:5). This feeling is described as a feeling of dependence (Otto 1932:10). In reaction to this awareness humans construct an appropriate response which manifests in religion (Otto 1932:82). This is a theological explanation as to the origin of religion. This position is also clear from the theology of religion present in the opening section of the monumental work of Calvin, Institutie. In the opening section (Book I, chapter 3 paragraph 1, translation by Sizoo 1931:8) Calvin indicates that he is convinced that religion is a universal human phenomenon that must be explained as the effect of an innate semen religionis ('seed of religion') and a sensus divinitatis ('sense of divinity'), stating that humans have a natural knowledge of the Divine. Such innate facilities can be traced back to God's creation of man. God re-ignites this awareness of the divine by 'adding droplets' from time to time to human existence. Religion is thus part of human nature. Ontologically humans have been predetermined to participate in religion.

I however think that the issue which we refer to as religion functions within a layered matrix. The layers determine what constitutes religion. Three layers can be mentioned here: culture, ethics and worldview. Of course many of the elements now indicated as religious are culturally constructed. Traditions (i.e. myths) are passed on from one generation to the next, instructing ways of believing, acting and thinking. In this sense Mulder (1985:35) is correct to say that religion is cultural expressions. Ethics however also influences what is called religion. I concede that ethics is included in cultural transference, but ethics functions also on a psychological level. Personal decisions as to what constitutes good behaviour influence and determine religious expressions. The Kantian argument of innate human ethical awareness applies here. The third layer in the matrix is worldview. The way in which individuals construct reality (compare Berger 1999:13) includes an understanding of a higher power from where everything originated from. Within this matrix the innate awareness (the sensus divinitatis Calvin talks about) is incarnated in cultural guise. These different culturally determined expressions (i.e. rituals, ethics, doctrines, etc.) are all attempts at materialising the response to the abstract metaphysical. That what is called religion is socially constructed and kept intact by social consensus (Berger 1967:125). That is the reason why it is difficult to state that some elements are not, or no longer, religious, as social consensus is required.

If religion is the essence of Religious Studies what does this essence consist of? Capps (1995:331) clearly indicates that Religious Studies exists of multiform subject fields with a variety of disciplines and a multiplicity of issues, interests and topics. This has been illustrated with the mentioning of the list Morreall and Sonn (2012) provided. There is in fact no single subject and not only one method of approach. This diverse and multifaceted nature of religion leads Braun (2000:9) to suggest that 'religion' can only be utilised as concept. It can no longer be used to refer to elements considered religious. A concept is a category used to order objects and to explain the nature, origin, relations and function of these objects according to the concept. The idea of religion as concept led Smith (1982:xi) to conclude that religion has no independent existence apart from academic activities. Religion is a creation by scholars to assist them in arranging data for research. As there exist no data for religion it is up to the scholar of religion to consciously compare phenomena, human experiences or expressions and provide reasons for the comparison. Religion, according to Smith, only exists (in the Western world) as academic category.

Olson (2011:16) indicates how Jean-Luc Marion referred to religion as a 'saturated phenomenon'. With this, Marion implies that religion has an excessive nature and therefore religion becomes invisible in its excessiveness. The result is that there is no one concept that captures the essence of religion (Olson 2011:16). This reflects the concept of religion functioning within a layered matrix discussed earlier.

Over time the Euro-centric understanding of what constitutes religion ended in a demarcation of the world between religious (i.e. everything resembling Western and European traditions and culture) as opposed to no religion (i.e. everything non-European). Combined with this development is the Enlightenment notion that knowledge resides in facts. Facts can only be studied empirically. Any study of the transcendental seems superfluous due to the un-empirical nature of the transcendental. Studying human reaction and responses to the transcendental can be studied empirically. In this way, the Science of Religion started as science as opposed to Theology, which was relegated to the domain of 
personal opinion. This situation has changed so that Theology is undeniably considered a science (Pannenberg 1973:247).

After some remarks have been made on the nature of religion, an explanation of the methodology utilised in Religious Studies may be necessary.

\section{Methodology of Religious Studies}

As to describing the 'dragon' of methodology, it has already been mentioned that a great variety of methods and approaches ${ }^{4}$ within Religious Studies already exist. Olson (2011:13) refers to the cross-cultural and multimethodological approach of Religious Studies. Compare in this regard the seminal work of Stausberg and Engler (2011) and Chryssides and Greaves (2007) where the multitude of methods and approaches in Religious Studies is not only identified but also discussed. For this reason, Willi Braun (2016:1) indicates that a new tendency is rather to focus on a theory of religion when research in matters of religion is attempted. Religious Studies has become 'theory-orientated'. The danger is however that the forest of theories can obscure the true object of investigation to such an extent that only the theories become visible and becomes the issue that is studied.

The methods to be employed when studying religion are most certainly determined by religion itself. Pannenberg (1973:372) sees the task of Religious Studies not only to arrange the occurrence of religious material in chronological order but also to create models how to understand the processes of development of single religions and world religions. In order to do this, a theory of history and a theory of religion are necessary.

A method is never an end in itself but always wants to lead to knowledge. It therefore becomes obvious that the more methods used, the richer the explanation or understanding resulting from the process of investigation. In this sense a method indeed becomes a tool. A method becomes a trap the moment a scholar's personal interest and identity pre-determines the method to be used. Compare in this regard how Rita Gross (2005:154) states that a method should be a tool and not an ideology. This can indeed happen when Theology becomes the sole lens through which religion is investigated. If this becomes the case, a predetermined conclusion is already assumed to determine the outcome of an investigation. Then the method becomes a trap.

It would also be appropriate when the limitations of each method are acknowledged. When a method can no longer provide answers required or a method only functions best in combination with another method, this should be taken into account. Compare in this regard the argument Cox (2010:169) has for getting the best results when combining cognition and phenomenology as methods for studying religion.
Religious Studies in all its trajectories has a task to describe and not to explain (Capps 1995:333). This can be at times complemented by functional accounts. Describing religious phenomenon can end up in a positivistic approach, relying on information presented by the senses. Phenomenology provides a solution by allowing phenomena to speak for themselves, on the condition that the investigator brackets the own assumptions, that which Edmund Husserl has termed epoche (Krüger 1982:17-18). Phenomenology seeks to unveil what lies behind the phenomenon (i.e. intentionality) under investigation (Krüger 1982:17). The reasons why people perform certain rituals or believe certain things are the true object of attention. Cox (2010:165) however indicates how cognition has become the most current method of investigating religion. Cognition relies on the fact that religion is an innate predetermined capability of the human mind. Humans have been 'wired' to accept religion (Boyer 2001:4). This corresponds to Calvin's concept of sensus divinitatis.

This section does not intend to provide an exhaustive overview of all methods for Religious Studies. What becomes apparent is the multiplicity of methods. Each situation (whether it be a historical, textual, social or psychological context) requires an appropriate method to optimise results. This once again acknowledges the multilayered matrix concept within which religion functions.

\section{Religious Studies in relation to Theology}

The plausibility of a combination of Religious Studies and Theology at a university is discussed by David Ford (2005). For Ford (2005:90), the same reasons as Schleiermacher presented in 1809 at the founding of the University of Berlin to include Theology at a university still apply today: Theology is training for a profession to serve in society. If the task of a university is to provide in the professional labour for society, Theology ought to be included. As to the combination of religion, Ford (2005:91) indicates that students need to be educated to be able to cope with the religious nature of society. Even though a university can claim to be secular or state run, the same reasons for including Theology and Religious Studies in the curriculum on university level still apply today. South African society is a highly religious society. It is only responsible to train students to be able to cope with this religious environment.

Worldwide there is a growing awareness of the need for knowledge of religions. This becomes apparent in the growing interest in studying religion amidst interreligious tension and conflict. The reason Chitando (2008:118) provides for this phenomenon witnessed across Southern Africa is that students in Southern Africa in particular have been exposed to religious education from an early stage in their education, whether it is missionary schools or churches in local communities. This seems to be part of the explanation for the growing number of students enrolling for the course 
Religious Studies at the University of Pretoria. Growth of Religious Studies indicates that worldwide there is a growing tendency not to study Christianity in isolation (Olson 2011:13). These tendencies have implications for the relation between Religious Studies and Theology.

As seen from the brief description of the historic development of Religious Studies, a period of consolidation and being recognised as a discipline saw its relationship with Theology come under pressure from time to time. The Swiss theologian Karl Barth went to great lengths to argue the difference between Science of Religion (Religious Studies) and Theology. He was concerned about what he saw as the rise of 'Natural Theology' within theological faculties. He called it a Trojan horse within Theology (in Pannenberg 1973:320). He blamed Science of Religion for the growing influence of Natural Theology in Theology and Church. Consequently, he called for the banning of Science of Religion from the theological faculties. Religion reflects the sinful human manner to search for God without acknowledging the revelation of God, relegating religion to the domain of idolatry (Barth 1979:327).

Barth's stance on Science of Religion was the result of the dominant position of the subject in most faculties of Theology at the end of the 19th century, as well as the way Theology functioned. He understood Theology's prime concern not to be that of academia but of the Kingdom and revelation of God in Christ.

As a result, many faculties of Theology began to reconsider the position and role of Science of Religion. The same happened in Science of Religion itself. This led to a minor exodus from Theology to Arts. (On the other hand many theological faculties in Europe, the UK and North America still harbour Science of Religion.)

Interest in Science of Religion waned somewhat after the seventies of the 20th century. By this time the culture of schools and dominating individuals was gone. A lot of attention was directed towards methodological issues. On the other hand, Theology developed a new interest in religion as phenomenon and in the non-Christian religions. The reason for this was the growing religious plurality of modern societies.

The difference between Theology and Religious Studies is described by Braun (2000:7) in an antithetical manner. The moment the study of religion was intended to be from a nonparticipant, but observer perspective, a difference was created between explaining and describing. A difference between the scientific study of religious phenomena as against studying the content of, say Christianity, signified the difference between Theology and Religious Studies. The two positions developed along the line of 'this' but 'not this' (Braun 2000:7). This resulted in Religious Studies to almost include everything and anything within its scope.

The issue separating Religious Studies and Theology seems in fact to be the binding element. Religious Studies is focused on investigating the human expression of encounters with the transcendental, emphasising human action. Friedrich Heiler claimed that Religious Studies has 'humanised' religion and made religion devoid of all gods (Pannenberg 1973:366). This however stands in contrast to Heiler's description that all Religious Studies is in fact Theology as Religious Studies is not only concerned with psychological and historical investigations but also concerned with the experience of the supernatural reality (Pannenberg 1973:367). All religious experience is concerned with a mystical essence. Although Religious Studies emphasises the human participation in the encounter with the transcendental and Theology focuses on the transcendental, both are concerned with the transcendental or metaphysical. This notion posed by Heiler will guide us in our further exposition of the relation between Religious Studies and Theology.

Mulder (1985:41) identifies Theology's interest in the question of truth as the major difference between Religious Studies and Theology. Religious Studies is not concerned with the question of truth of any expression of religious encounter. All expressions of belief according to Religious Studies are valid and true. Theology however provides an evaluative answer from a Christian perspective as to what true and valid expressions of faith are. Pannenberg (1973:370) indicates how Colpe states that Religious Studies rather is concerned with the validity of religious claims whereas Theology is concerned with the truth of claims.

Perhaps the more pressing question should be to ask why would any Faculty of Theology entertain the idea of hosting Religious Studies? Surely the reason cannot be to symbolically acknowledge the plurality of the religious environment. It also can no longer be (as historically has been the case) an attempt by Christians at getting to know what others believe and then pounce on their weaknesses in order to convert them (Pannenberg 1973:364). It also cannot be an expression of power how one religion associated with a particular culture can manipulate and oppress other cultures. The pure motive for Theology to host Religious Studies much rather should lie in the shared interest in understanding religion in a social dimension and how diverse the expressions of the encounters with the transcendental can be. This will include understanding the religion known as Christianity as part of the religious world. Understanding the other includes understanding the self (Pannenberg 1973:364).

Theology is not only associated with Christianity (Olson 2011:13). Theology is much more in a present-day academic environment considered to be part of the intellectual heritage of various religious traditions. It is therefore possible to talk about Muslim Theology or Hindu Theology or Jewish Theology. Muslims, for example, believe in the existence of God and discuss his qualities (Mulder 1985:42), as would Jews and Hindus and Bahá'í's.

At the University of Pretoria the presence of the subdiscipline of Science of Religion within the Department of Science of Religion and Missiology has a historical explanation. 
With the development of Science of Religion at European universities ${ }^{5}$ the situation occurred where certain churches with certain confessions affiliated with certain faculties of Theology in Germany. Science of Religion then became part of a particular university with a Faculty of Theology subscribing to certain doctrines. Science of Religion was then practised from a particular doctrinal stance. The result was that religions were studied with Christian interests and perspectives. Other religions were mostly studied in as far as they were perceived as objects of mission. Christianity was portrayed as an (superior) example of religion.

This might have been the conditions under which religions were similarly studied at the University of Pretoria, especially during a period in the South African history when there was little tolerance for anything non-Christian. Conditions however have changed.

Post-colonial and post-foundational Theology made scholars aware of the danger of a predetermined (ideological) approach to understanding. The insights of Ezra Chitando provide some light on the possible future connection between Theology and Religious Studies.

Religious Studies has, according to Chitando (2008:106), emerged out of the matrix of Theology. This cannot be denied. The effort, however, to break the connection between Religious Studies and Theology is part of a post-colonial process. Chitando (2008:107) indicates how conscious efforts were employed to rename and restructure tertiary education institutions in Africa since the 1960s which saw the dawn of the decolonisation period. 'Theology' was replaced with the name 'Religious Studies' to reflect the religious pluralistic environment of Africa. The scepticism, with which the results of Religious Studies research associated with a Faculty of Theology are treated, is a continuation of this post-colonial process.

Part of the scepticism towards Religious Studies is the stigma that it traditionally cannot be differentiated from religious instruction or even indoctrination (Chitando 2008:108). As Chitando (2008:103) points out, one of the problems in the sub-Saharan region is that Religious Studies is practised by religious people who has some distinct religious affiliation. In some African regions (i.e. Nigeria), no sharp distinction between Religious Studies and Theology is maintained. In South Africa, however, Religious Studies and Theology seem to exist in some tension (Chitando 2008:103). Where Religious Studies is undertaken at theological training institutions and faculties of Divinity, a certain aversion towards research results emanating from such institutions exists. The results are perceived, rightly so or not, to be 'contaminated' by theological perspectives. The perception is created that true Religious Studies can only be practised from a secular stance.

The fact is that Religious Studies at a Faculty of Theology can indeed present responsible and valuable insights. A theology

5.Compare the historic overview that Pannenberg (1973:361-362) provides. of religion is indeed necessary to understand the very nature and origin of religion. The ways in which the encounters with the metaphysical are culturally expressed and socially maintained are part of the focus of Religious Studies. This is a theological activity and thus an academic endeavour, adding to knowledge. In this way, Religious Studies can indeed contribute to the field of knowledge even from a theological background.

Chitando (2008:109) suggests major topics to be considered by Religious Studies in Southern Africa. Religious Studies ought to focus on African Traditional Religions as these are no longer considered superstition or magic. It is considered a religion and worthy of academic interest. Religious Studies should focus on African Christianity, on religion and ecology, on religions and healing and New Religious Movements.

Based on the nature of Religious Studies there is place for it within a Faculty of Theology: particularly to assist Theology in determining a theological anthropology. The task is to understand the way humans act and react and interact within reality and with the mystic reality or transcendental.

Chitando (2008) identifies certain fields of collaboration where Religious Studies and Theology can enrich one another:

Pentecostalism in Africa related to social and economic crises

Environmental issues

'Reading' traditions: texts or oral traditions

Role of women in religion

Religion and HIV / AIDS. (pp. 120-121)

Based on the suggestions made by Chitando, I believe the following elements can be added to the list above:

- religion and art

- interreligious communication

- religion and technology

- religion as traditional knowledge system.

I think a further exposition on the contribution Religious Studies can make to the traditional disciplines within Theology can be indicated as follows:

- In Practical Theology Religious Studies can contribute by studying forms of worship (rituals and liturgy). Such study will include a phenomenological investigation of different rituals. Mulder (1985:40) emphasises that knowledge of religious phenomena contributes to Theology.

- In Old and New Testament studies Religious Studies can contribute by comparing how different religious traditions treat textual studies. The status and role and exegesis of holy literature can contribute to knowledge.

In Church History the history of religions can contribute to understand the influences of other religions on the origin of Christianity in order to understand Christianity itself (Mulder 1985:40). 
In Missiology Religious Studies can facilitate interreligious communication (Capps 1995:340) and even through comparative religion understands the social role of religion. Pannenberg (1973:364) suggests a strict separation between Missiology and Science of Religion in order not to confuse missionary interests when studying other religions.

In Systematic Theology and ethics, two main areas of collaboration can be identified: interreligious ethics and mysticism which focuses on the relation between immanence and transcendence. This can include a comparative study. Mulder (1985:40) is of the opinion that understanding other religions can contribute to the establishment of ecumenical relations with non-Christian religions.

Religious Studies should however not only be seen as an addition to Theology but as a discipline in its own right. The need for a philosophy of religion is clearly an essential part of studying religion. A discussion on meta-religious matters is part of the unbiased task of Religious Studies. It becomes clear that Religious Studies can function as an interdisciplinary bridge between Theology and other disciplines such as philosophy, sociology, psychology, education, law (in terms of human rights) and medicine.

\section{Conclusion}

Seeing dragons does not mean conquering dragons. To be aware of the hindrances in understanding Religious Studies does not automatically mean that all problems have been solved. In fact the problem starts only now, namely seeking solutions for a peaceful coexistence of Religious Studies and Theology.

Now that the problem areas have been identified (i.e. what is religion; what methods does Religious Studies employ and what is the relationship between Religious Studies and Theology), an anticipatory suggestion as to the manner in which Religious Studies can be hosted at a Faculty of Theology can be made.

From the discussion above, it is clear that there is space for Religious Studies at a Faculty of Theology. I however think that it would only be responsible to differentiate between Religious Studies and Theological Religious Studies (currently known as Science of Religion). The differentiation is a clear indication of two distinct approaches which can be housed under one roof. Both approaches focus on the same, namely religion, and both intend to contribute to the knowledge of religion. Only the approaches differ. Religious Studies focuses on the human expression (an approach so to speak from below) and Theology focuses on the transcendental with which humans engage (an approach so to speak from above). Theological Religious Studies would then be the study of non-Christian religions from a Christian perspective and with a Christian interest. This will include establishing a theology of religion and theology of religions. Religious Studies will then be the humanistic approach to studying religious matters. Both will contribute to the understanding of religion.
A second condition would be to demarcate Religious Studies further by indicating that the area of focus for Religious Studies is religion and not something else. It is not society that is studied (although a certain amount of overlapping between Sociology of Religion and Religious Studies does occur). ${ }^{6}$ The same applies to psychology of religion. Scholars in Religious Studies are not quasi-sociologists or quasipsychologists. Religious Studies focuses on the social dimension of religion and not on religion as a social phenomenon. Religious Studies can also not pretend to be Theology. Even if Theology can be interpreted as describing a universal approach which can also be used to label a Muslim or Hindu or Christian approach, by being a non-doctrinal study of religious matters, Religious Studies does not operate on the same level as Theology. Both disciplines can however contribute to and enrich the other. This has clearly been indicated in a discussion above where fields of contact have been identified.

Heiler's statement that all aspects of Religious Studies are in fact Theology (Pannenberg 1973:367) is an important guideline. Both disciplines are concerned with the mystical reality of the transcendental. The scope of Religious Studies is just wider than the scope of Theology, which is limited to the Christian understanding that God reveals him in Jesus Christ. Religious Studies considers all possible ways in which contact with the transcendental can be expressed without questioning the truth of it. In this way both disciplines contribute to understanding.

Our journey through the forest of knowledge has not brought our quest to understand Religious Studies to an end. The journey has made us aware of the dangers (dragons) lurking in the arguments. The journey hopefully has also shed some light on possibilities for locating Religious Studies within a Faculty of Theology.

\section{Acknowledgements Competing interests}

The author declares that he has no financial or personal relationships which may have inappropriately influenced him in writing this article.

\section{References}

Barth, K., 1979, Kirchliche Dogmatik, 1/2. 2. Aufl, Theologischer, Verlag, Zurich.

Berger, P.L., 1967, The sacred canopy: Elements of a sociological theory of religion, Anchor Books, New York.

Berger, P.L., 1999, 'The desecularization of the world', in P.L. Berger (ed.), The desecularization of the world: Resurgent religion and world politics, pp. 1-18, WB Eerdmans Publishing Company, Grand Rapids, MI.

Beyers, J., 2010, 'What is religion? An African understanding', HTS Teologiese Studies/ Theological Studies 66(1), Art. \#341, 1-8. http://dx.doi.org/10.4102/hts.v66i1.34

Boyer, P., 2001, Religion explained. The evolutionary origins of religious thought, Basic Books, New York.

Braun, W., 2000, 'Religion', in W. Braun \& T. McCutcheon (ed.), Guide to the study of religion, pp. 3-18, Cassell, London.

Braun, W., 2016, 'Colloquium on method and theory: Introduction', in Method and theory in the study of religion, vol. 28, pp. 1-2, Brill, Leiden. http://dx.doi. org/10.1163/15700682-12341345

6.Compare Krüger (1982:9) 
Calvin, J., 1931, Institutie: Of onderwijzing in de Christelijke godsdienst, transl. A Sizoo, Book 1. W.D. Meinema, Delft.

Capps, W.H., 1995, Religious studies: The making of a discipline, Fortress Press, Minneapolis, MN.

Chitando, E., 2008, 'Sub-Saharan Africa', in G.D. Alles (ed.), Religious studies: A global view, pp. 103-125, Routledge, London.

Chryssides, G.D. \& Greaves, R. (ed.), 2007, The study of religion: An introduction to key ideas and methods, Bloomsbury, London.

Cox, J.L., 2010, An introduction to the phenomenology of religion, Continuum Publishing Group, New York.

Ford, D.F., 2005, 'Faith and universities in a religious and secular world', Svensk Teologisk Kvartalskrift. Arg 81, 83-91.

Gross, R.M., 2005, 'Methodology - Tool or trap? Comments from a feminist perspective', in R. Gothóni (ed.), How to do comparative religion? Three ways, many goals, pp. 149-166, Walter de Gruyter, Berlin.

Krüger, J.S., 1982, Studying religion: A methodological introduction to science of religion, University of South Africa, Pretoria.

Morreall, J. \& Sonn, T., 2012, The religion Toolkit: A complete guide to religious studies, Wiley-Blackwell, Chichester.

Mulder, D.C., 1985, 'Het vak godsdienstwetenskap', in D.J. Hoens, J.H. Kamstra \& D.C. Mulder (eds.), Inleiding tot de studie van godsdiensten, pp. 35-40, J.H. Kok, Kampen.

Olson, C., 2011, Religious studies: The key concepts, Routledge, London.
Otto, R., 1932, Das Heilige: Über das Irrationale in der Idee des göttlichen und sein Verhältnis zum Rationalen, C.H. Beck'sche Verlagsbuchhandlung, München.

Pannenberg, W., 1973, Wissenschaftstheorie und Theologie, Suhrkamp Verlag, Frankfurt am Main.

Schilbrack, K., 2016, 'Towards a philosophy of religious studies: A response to critics', Method and Theory in the Study of Religion 28, 98-111. http://dx.doi. org/10.1163/15700682-12341359

Schilderman, H., 2014, 'Defining religion: A humanities perspective', in H. Schilderman (ed.), The concept of religion: Defining and measuring contemporary beliefs and practices, pp. 176-198, Brill, Leiden.

Smith, J.Z., 1982, Imagining religion: From Babylon to Jonestown, University of Chicago Press, Chicago, IL.

Stausberg, M. \& Engler, S. (ed.), 2011, The Routledge handbook of research methods in the study of religion, Routledge, New York.

Sundermeier, T., 1999, Was ist Religion: Religionswissenschaft im theologischen Kontext, Gütersloher Verlagshaus, Gütersloh.

Thorpe, S.A., 1992, Primal religions worldwide: An introductory, descriptive review, University of South Africa, Pretoria.

Urban, O.H., 2003, 'Religion der Urgeschichte', in J. Figl (ed.), Handbuch Religionswissenschaft: Religionen und ihre zentralen Themen, pp. 88-103, TyroliaVerlag, Innsbruck.

Van der Leeuw, G., 1970, Phänomenologie der Religion. 3, Auflage. J.C.B. Mohr, Tübingen. 